\title{
SOBRE SAN JUAN DE LA CRUZ Y SOBRE LA HISTORIA DE LAS IDEAS LITERARIAS
}

Francisco ABAD Nebot

UNED

I. CaRacteres del estilo artístico y lingǘstico de SAN JUAN DE LA CRUZ*

\section{*Imaginativa y *fantasía*}

Los Siglos de Oro españoles registraron lo que don Julio Caro ha llamado «inmensa» producción de libros de temática religiosa, y ello sin duda es uno de

* Estas primeras páginas constituyen la versión escrita de la comunicación que expusimos oralmente en el Congreso Internacional Sanjuanista celebrado en Avila en 1991, y que -a iniciativa de alguno de los colegas asesores de ese Congreso- no ha aparecido en las Actas; el texto tampoco se nos ha devuelto hasta ahora.

Lamentamos que a estas alturas puedan ocurrirle tales cosas a un profesor cuya vocación por el estudio y cuya honradez y compromiso ético con la carrera académica de sus compañeros y sus alumnos resultan unánimemente reconocidos. Lo peor de estos hechos (y de otros análogos) es que sientan precedentes institucionales que acaban afectando a más de una y más de dos personas, y que incluso - puede demostrarse - llegan a afectar a la vida universitaria de los propios alumnos.

Ricardo Senabre se ha visto obligado a escribir - a propósito de una estimación que se ha hecho de nuestra filología reciente-, que «constituye un muestrario de arbitrariedades». 
los rasgos que definen su cultura, aunque escribir sobre un tema de esta manera en apariencia obsesiva «puede producir trastornos»; en el conjunto sin embargo nos encontramos con «el tope máximo de la mística» ${ }^{2}$. Estamos en efecto ante una actividad «teológico-humanística» esencial, y ante una actividad científica -al margen de su calidad - limitada ${ }^{3}$, pero como queda dicho con una altura máxima de la mística.

En ella aparece San Juan, quien argumenta acerca de que las aprehensiones imaginarias naturales no pueden ser medio para llegar a Dios y hay que procurar desasirse de ellas:

Es pues de saber - manifiesta- que los sentidos de que aquí particularmente hablamos son dos sentidos corporales interiores que se llaman imaginativa y fantasía, los cuales ordenadamente se sirven el uno al otro porque el uno discurre imaginando, y el otro forma la imaginación o lo imaginado fantaseando... Y así a estas dos potencias pertenece la meditación, que es acto discursivo por medio de imágenes, formas y figuras, fabricadas e imaginadas por los dichos sentidos, así como imaginar a Cristo Crucificado o en la columna o en otro paso, o a Dios con grande majestad en un trono,... Todas las cuales imaginaciones se han de venir a vaciar del alma, quedándose a escuras según este sentido para llegar a la divina unión $^{4}$.

El alma por tanto ha de quedar vacía de las figuras y formas a que han dado lugar la imaginativa y la fantasía, para así llegar hasta la unión divina: ninguna cosa puede tener proporción con el ser de Dios, y ninguna que imaginemos puede servir de medio próximo para la unión con Él.

De esta manera argumenta San Juan, quien completa su pensamiento al afirmar que «a los principiantes son necesarias estas consideraciones y formas y modos de meditaciones» a través de los sentidos, que pueden servirles de medio remoto para unirse con Dios 5 .

1 J. Caro Baroja, Las formas complejas de la vida religiosa, Madrid, Akal, 1978, pp. 31-32.

2 lbid., p. 32.

3 lbid., p. 615.

4 «Subida del Monte Carmelon, en Vida y Obras de San Juan de la Cruz, Madrid, BAC, MCMLXIV ${ }^{5}$, pp. 363-538: pp. 417b-418a.

5 Ibid., p. 418a. 
En la prosa sanjuanista vemos que han aparecido las palabras «imaginativa», «fantasía» e «imaginaciones», las cuales vamos a anotar léxicamente. «Imaginativa» tiene el sentido de «potencia o facultad de imaginar»; Corominas menciona el vocablo sin indicación alguna, y tampoco está en Covarrubias, por lo que este pasaje importante sanjuanista puede servirnos de referencia histórica ${ }^{6}$.

«Fantasía» aparece en el pasaje con la acepción de «representar por medio de imágenes las cosas ideales». La palabra está en Juan Ruiz:

Levantóse el griego, tendió la palma llana

e assentóse luego con su memoria sana;

levantóse el vellaco con fantasía vana,

Jacques Joset interpreta el significado de «con agitación exterior» ${ }^{7}$ y acaso tampoco «con fantasía vana» esté lejos de querer decir «con antojo», «con presunción», ideas que más o menos connotan todas ellas algo negativo, pues se opone (ha dicho el mismo Joset a partir de Morreale) al estatismo medieval referido en la «memoria sana».

Juan de Valdés escribió, como es sabido: «De la lengua italiana desseo poderme aprovechar para la lengua castellana destos vocablos:... fantasía en la sinificación que lo tomáis acá», o sea, "presunción»", y este sentido es el que encontramos en La vida de Lazarillo de Tormes: «Sólo tenía dél un poco de descontento, que quisiera yo que no tuviera tanta presumpcion, mas que abajara un poco su fantasía con lo mucho que subía su necesidad» 9 .

Las dos acepciones que venimos viendo - «imaginación», «presunción»- las registra Covarrubias ${ }^{10}$, y luego lo hace el Diccionario de la lengua castellana o Diccionario de Autoridades ${ }^{11}$; Gili Gaya cree «fantasía» palabra si-

6 Joan Corominas, Diccionario Crítico Etimológico Castellano e Hispánico, Madrid, Gredos, 1980 ss.; Sebastián DE CovarRubias, Tesoro de la Lengua Castellana o Española, ed. por Martín de Riquer, Barcelona, Horta, 1943.

7 ARCIPRESTE DE HITA, Libro de Buen Amor, ed. de Jacques Joset, Madrid, Espasa-Calpe, $1981^{2}$, I, p. 30 y n.

8 Juan DE VAldEs, Diálogo de la lengua, ed. de Cristina Barbolani, Madrid, Cátedra, 1982, p. 221.

${ }^{9}$ Ed. de Francisco Rico, Madrid, Cátedra, 1987, p. 92.

10 Ed. cit., p. $584 b$.

11 Tomo quinto, p. $248 b$. 
nónima de «imaginación», de «capricho, antojo», y de «presunción, ostentación" ${ }^{12}$. El pasaje de Juan Ruiz, los distintos testimonios de Gili, etc., hacen que lo dicho por Corominas pueda ser reformulado con más precisión; enuncia en efecto este grandísimo lingüista: «FANTASIA... Tiene desde el principio, con ligeras variaciones, el sentido moderno... Juan de Valdés lo pone en su lista de palabras italianas... Se trata del sentido específicamente italiano «capricho», "voluntad caprichosa», que por lo demás no logró Valdés aclimatar en español» 13 .

En fin hemos visto a San Juan referirse a las «imaginaciones» o «imágenes formadas por la fantasía» que se han de vaciar del alma; Nebrija anota en su Lexicon o Diccionario latino-español: «Imaginatio... por vision de imagenes», y luego en el Vocabulario español-latino escribe: «Imaginacion.imaginatio» ${ }^{14}$. «Imaginaciones» son por tanto las «imágenes vistas» en la fantasía.

\section{«Imágenes*}

San Juan de la Cruz postula que se ponga la devoción en lo invisible, y que se aniquile el afecto que pueda tenerse en las cosas particulares, aunque cuando sirvan como medio para la unión con Dios resultan necesarias, y han de tener no el valor del ornato sino la capacidad de mover a devoción:

El uso de las imágenes - proclama - para dos principales fines le ordenó la Iglesia, es a saber: para reverenciar a los santos en ellas y para mover la voluntad y despertar la devoción por ellas a ellos; y cuanto sirven desto son provechosas y el uso de ellas necesario. Y por eso las que más al propio y vivo están sacadas y más mueven la voluntad a devoción se han de escoger, poniendo los ojos en esto más que en el valor y curiosidad de la hechura y su ornato ${ }^{15}$.

12 Samuel Gili GaYA, Diccionario de sinónimos, Barcelona, Biblograf, 1968 ${ }^{3}$, pp. 174b $175 b$.

13 Diccionario..., II, pp. 851 b-852 b.

14 Elio Antonio de NeBriJa, Diccionario Latino-Español, est. preliminar por G. Colón y A-J. Soberanas, Barcelona, Puvill, 1979; Vocabulario Español-Latino por Elio Antonio de NeBriJA, Madrid, RAE, 1951.

15 «Subida del Monte Carmelom, p. 524a-b. 
El uso de las imágenes se limita pues a que puedan mover la voluntad a devoción; resultan de provecho - dice en otro momento- «para acordarse de Dios y de los santos» 16 .

Emilio Orozco ha glosado bien cómo San Juan no se preocupa de la perfección de la forma sino de lo expresivo: lo que importa es que la imagen «sea realista - dice-, que impresione vivamente» y despierte la devoción ${ }^{17}$; de ello deriva la analogía del ideal estilístico de los místicos con el de los barrocos ${ }^{18}$.

En el texto sanjuanista aparece el vocablo «imágenes» en el sentido de «estatua, efigie o pintura de Dios, la Virgen o los santos»; treinta o más años antes que en Berceo - primera documentación que alega Corominas-, la palabra está por lo menos en la Vida de madona Santa Maria Egipciaqua, que dice:

Tornó la cara on sedía:

vio huna imagen de santa María.

La imagen era bien figurada, en la mesura era tajada ${ }^{19}$.

Las «imágenes» - glosaba Covarrubias- ya indicó Santo Tomás que pueden mover a devoción, de acuerdo a la vez con la idea horaciana de que lo que entra por los ojos causa mayor impresión que lo que conocemos por el oído:

Segnius inritant animos demissa per aurem quam quae sunt oculis subiecta fidelibus et quae ipse sibi tradit spectator ${ }^{20}$.

16 Ibid., p. 527 a.

17 E. Orozco, Mística, Plástica y Barroco, Madrid, Cupsa, 1977, p. 46.

18 «Este paralelismo entre la estética de los místicos y la estética del Barroco - escribe el mismo autor-... en parte hay que considerar no sólo como fenómeno de coincidencia, sino como de iniciación y antecedente. Su doctrina estética supone una valoración de lo vivo y expresivo - de lo que mueve- sobre la corrección y perfección normal, distinta o más bien contraria a una concepción clasicista e idealista cual corresponde al pensamiento artístico del Renacimiento» (ibid., p. 58).

19 Ed. de Manuel Alvar, Madrid, CSIC, MCMLXXII, pp. 66-67, con la corrección de una errata de imprenta.

${ }^{20}$ Covarrubias, p. 732a-b; Horace, Epitres, Paris, Les Belles Lettres, 19676, p. 212. 
Erasmo por ejemplo mantenía que «has de tener por remedio universal y maravilloso, sobre todos, el misterio de la cruz y passión de Christo» ${ }^{21}$; San Juan como se sabe hizo un dibujo de Jesucristo en la cruz, en el que los especialistas han visto una imagen de las que efectivamente mueven a devoción: «Se ve el Cristo muerto - comenta Orozco- que pende de los brazos de la cruz, doblándose las rodillas al peso del cuerpo cual si fuera a desgarrarse y caer hacia delante. La cabeza cae también pesadamente sobre el pecho, envuelta por una espesa cabelleras 22 .

La doctrina y el dibujo de San Juan de la Cruz resultan por tanto convergentes y coherentes entre sí, y se desarrollan en el marco de un ideal espiritual y realista en parte y análogo al del Barroco.

\section{Conciencia expresiva: estudio y elección}

«Un extraordinario culminar de la literatura religiosa» se desarrolla aproximadamente en los treinta años que van de 1555 a 1585 , entre fray Luis de Granada y San Juan; nuestro autor en concreto escribe de 1578 a $1586^{23}$. El propio don Ramón ha destacado algunos rasgos de la lengua del Santo, aunque se ocupa de él muy brevemente; como idea general que podrá ser ampliada enuncia (y lo hace en un artículo suyo casi nunca utilizado):

San Juan expone a veces los estados místicos en un lenguaje prosístico doctrinal y razonador que camina entre frecuentes conjunciones consecutivas y causales.... pero más veces escribe su prosa en tensión poética con la liricidad imaginativa que exige el análisis del alma... La lengua poética comienza [en él] a desviarse en formaciones morfologicas y fraseológicas nuevas ${ }^{24}$.

21 ERASMo, El Enquiridion o Manual del caballero cristiano, ed. de Dámaso Alonso, Madrid, CSIC (reimpresion), 1971, regla XVII.

22 Mistica..., p. 54.

23 Son momentos destacados por Menéndez Pidal: R. MENÉndez PIDAl, «El lenguaje del siglo XVI», La lengua de Cristóbal Colon, Madrid, Espasa-Calpe, 1968 ${ }^{5}$, pp. 47 ss.: p. 73, y «El lenguaje español en tiempo de Felipe II*, en El Escorial. 1563-1963, Madrid, Patrimonio Nacional, 1963, I, pp. 531-562: p. 543.

24 \&El lenguaje español...», pp. 543-544. 
A estos usos subyace sin embargo una conciencia linguística sanjuanista que podemos establecer.

Manuel García Blanco ha interpretado -creemos que con acierto- como ideal de estilo de nuestro autor el de «inspiración y selección»: sabido es que él mismo decía que sus palabras unas veces se las daba Dios y otras tenía que buscarlas por su cuenta ${ }^{25}$. No obstante en ocasiones manifestaba que las noticias de Dios que sentía en el alma no tenía términos con que expresarlas, ni era capaz de darlas a entender; en la Subida del Monte Carmelo escribe San Juan:

Este género de noticias... unas acaecen al alma acerca del Criador, otras acerca de las criaturas... $\mathrm{Y}$ aunque las unas y las otras son muy sabrosas para el alma, pero el deleite que causan en ella estas que son de Dios no hay cosa a qué le poder comparar, ni vocablos ni términos con qué le poder decir, porque son noticias del mismo Dios y deleite del mismo Dios... Que, por cuanto es pura contemplación, ve claro el alma que no hay como poder decir algo de ello, si no fuese decir algunos términos generales que la abundancia del deleite y bien que alli sintieron les hace decir a las almas por quien pasa; mas no para que en ellos se pueda acabar de entender lo que allí el alma gustó y sintio $6^{26}$.

La lengua puede valerse de términos léxicos y de símiles para dar a entender algo, y esto es lo que San Juan enuncia: que para las noticias de Dios experimentadas en el alma («su omnipotencia», «su fortaleza», «su bondad y dulzura») no existen términos comparativos que las expresen, ni vocablos cuya significación las manifieste; sólo puede hablarse respecto de ellas en términos generales que no pueden darlas a entender.

A los principios de inspiración y de selección se une en la conciencia estjlística sanjuanista la creencia en la inefabilidad de los estados místicos: ni vocablos apropiados ni símiles existen para manifestar lo que el alma siente.

La misma idea la repite el Santo al inicio de la «Llama de amor viva»:

Alguna repugnancia he tenido, muy noble y devota señora -escribe-, en declarar estas cuatro canciones que V. m. me ha pedido, porque,

25 M. Garcia Blanco, «San Juan de la Cruz y el lenguaje del siglo XVI», en La lengua española en la época de Carlos V, Madrid, Escelicer, 1967, pp. 45 ss.: p. 47.

26 «Subida...», ed. cit., p. 461 a-b. 
por ser de cosas tan interiores y espirituales para las cuales comúnmente falta lenguaje (porque lo espiritual excede al sentido), con dificultad se dice algo de la sustancia ${ }^{27}$.

De nuevo vemos a San Juan exponer cómo para las cosas espirituales falta lenguaje con que manifestarlas, ya que lo espiritual excede a las experiencias humanas que podemos desarrollar y entre ellas la lingǘstica o expresiva.

Nuestro autor poseyó una activa conciencia de estilo, y por eso a propósito de su obra puede hablarse de selección en la inspiración, o-quizá mejor expresado - de inspiración, estudio y elección; ello explica que en su poesía existan raíces castellanas, cultistas y bíblicas que la crítica ha abordado ${ }^{28}$.

\section{El endecasilabo y la lira}

Del endecasilabo sanjuanista se había dicho que lo que de él resalta es la acentuación constante sobre la sílaba sexta; no obstante el análisis de don Tomás Navarro fue más concreto, y llegó a estos resultados:

a) la variedad rítmica predominante es la heroica;

b) , en segundo término el poeta hace uso de la variedad melódica, lo que supone una «nota característica en las canciones de este autor»;

c) San Juan «dio relativa representación a los versos con acentos en cuarta, sexta y octava, o simplemente en cuarta y sexta, los cuales equivalen prácticamente al tipo sáfico» ${ }^{29}$.

27 «Llama de amor vivam, Vida y Obras de San Juan de la Cruz, pp. 826-926: p. 826.

28 Eminentemente lo ha hecho (como se sabe) Dámaso ALonso: «La poesía de San Juan de la Cruz», ahora en O. C., II, Madrid, Gredos, 1973, pp. $869 \mathrm{ss.} \mathrm{Que} \mathrm{el} \mathrm{Santo} \mathrm{tuviese} \mathrm{la} \mathrm{intuición} \mathrm{de}$ que no podían encontrarse términos comparativos para manifestar las vivencias espirituales, no quiere decir que no ocurra lo que ha expuesto LAPESA: «A cada paso emplea giros o comparaciones fuertemente expresivos; en ellos se dignifican el afectivismo, la nota popular y hasta la que en otros casos sería trivial: «así se gozan en el cielo de que ya saque Dios a esta alma de pañales»; la purificación actúa sobre el alma "como el jabón y la fuerte lejla"»; vid. Rafael Lapesa, Historia de la lengua española, Madrid, Gredos, 19819. pp. 320-321.

29 T. Navarro TomAs, Métrica Española, Madrid, Guadarrama, $1972^{3}$, p. 203. 
Las variedades heroica, melódica y sáfica del endecasílabo son las que están presentes pues en la lírica sanjuanista, al igual que ocurre en general en los autores renacentistas.

La lira —como se sabe - es la estrofa de la «Noche oscura» y del «Cántico espiritual», mientras en la «Llama de amor viva» hace uso San Juan de la Cruz de la combinación «abCabC»; la canción a lo divino «Un pastorcico» consta de cinco cuartetos endecasilábicos de rima ABBA, y esta rima A permanece inalterada las diez veces en que aparece a lo largo de todo el poema (es la rima -ado). Dámaso Alonso ha comprobado estos hechos bien notorios por otra parte, $y$ además se ha detenido en los rasgos del «Cantar de la alma que se huelga de conoscer a Dios por fe», que consta de villancico inicial, dos endecasílabos pareados y estribillo: «Este tema desarrollado por San Juan... - concluye el critico- es verosímilmente un muy antiguo villancico tradicional perdido, en el que la $o$ de fonte... ha de ser explicada como dialectal» y apunta a occidente ${ }^{30}$.

El endecasílabo y la lira de San Juan de la Cruz sintetizan y a la vez simbolizan el hecho de la vigencia que alcanzaron entonces ambas formas métricas; con este auge del endecasílabo el modo de métrica silábica se oponía en el sucederse de la serie artística a la sonoridad rítmica practicada en el Cuatrocientos y heredada de él: frente al arte cuatrocentista de sonoridad y recurrencia insistentes, se alzaba y llegaba a una cumbre la métrica silábica de metro extenso ${ }^{31}$.

\section{Figuras del verso y de la prosa}

En la «Declaración» de la Canción 3." del Cantico espiritual San Juan va manifestando lo que en ella está oculto; efectivamente -y como anotó Covamubias - "declarar» es «manifestar lo que de suyo estava oculto, obscuro y no entendido» ${ }^{32}$. La canción dice:

Buscando mis amores, yré por esos montes y riberas; ni cogeré las flores,

30 «La poesía...», pp. 963ss. y 994 ss.

31 Vid. T. NAvarRo Tomás, op. cit., más algunas observaciones contenidas a lo largo de Los poetas en sus yersos. Desde Jorge Manrique a García Lorca, Barcelona, Ariel, 1973.

32 Ed. cit., p. 445b. 
ni temeré las fieras,

y pasare los fuertes y fronteras ${ }^{33}$.

Nuestro autor ha construido una alegoría y expone primero los dos términos metafóricos iniciales, montes y riberas:

A las virtudes llama montes -escribe-... Y llama riberas a las mortificaciones y sugeciones y desprecio de $\mathrm{si}^{34}$.

Luego se trata de «declarar» a qué hacen referencia las «flores»:

Dice que no cogerá las flores que encontrare en este camino, por las quales entiende todos los gustos y contentamientos y deleites que se le pueden ofrecer en esta vida, que le podrían impedir el camino si cogerlos o admitirlos quisiese ${ }^{35}$.

En fin San Juan ha de «declarar» también lo que se encuentra oculto tras las designaciones metafóricas fieras, fuertes y fronteras, y así escribe:

En los quales versos pone los tres enemigos del alma, que son: mundo, demonio y carne, que son los que hacen guerra y dificultan el camino. Por las fieras entiende el mundo, por los fuertes el demonio, y por las fronteras la carne $\mathbf{e}^{36}$.

Los versos tercero y cuarto de la estrofa presentan una anáfora más polisíndeton, y en ellos y en el quinto se da la bien conocida casi-paronomasia entre flores, fieras, fuertes, fronteras; esta isotopía de sonidos se produce además

33 San Juan de la Cruz, Cántico espiritual, ed. de Eulogio Pacho, Madrid, Fundación Universitaria Española, 1981, p. 586.

34 Ibid., p. 640.

35 lbid.

36 Ibid, p. 642. 
entre cuatro términos unidos asimismo conceptualmente, puesto que están referidos a los obstáculos que puede encontrar el alma en la búsqueda de Dios.

Anáfora, polisíndeton, paronomasia relacionada con el contenido y alegoría esmaltan el discurso sanjuanista; asimismo podemos ver «conjunción» en la prosa: «... las mortificaciones y sugeciones y desprecio de sí»; «por las quales entiende todos los gustos y contentamientos y deleites... ". La prosa además se estructura según bimembraciones que a veces están ocupadas por palabras sinónimas:

Y así, es como si digera: ni pondré mi coracón en las riqueças y bienes que ofrece el mundo, ni admitiré los contentamientos y deleytes de mi carne, ni repararé en los gustos y consuelos de mi espiritu, de suerte que me detenga en buscar a mis amores por los montes y riberas de las virtudes y trauajos ${ }^{37}$.

Las bimembraciones en efecto van marcando el ritmo de la prosa: «riqueças» $y$ «bienes»; «contentamientos» $y$ «deleytes»; "gustos» y "consuelos» (términos todos ellos aproximadamente sinónimos de dos en dos); «montes» y «riberas»; «virtudes» $y$ «trauajos».

\section{Conclusiones}

En las páginas presentes han venido a quedar abordados estos hechos:

1. En la doctrina de San Juan de la Cruz las «imaginaciones» creadas conjuntamente por los sentidos de la «imaginativa» y la «fantasía» tienen que ser vaciadas del alma para así conseguir la unión divina; a los principiantes en la experiencia religiosa, sin embargo, tales meditaciones por medio de figuras y formas pueden serles necesarias.

2. La voz «imaginativa» entendida en tanto «sentido corporal interior» aparece en la «Subida del Monte Carmelo» sanjuanista; se trata de un testimo-

37 lbid., pp. 641-642. 
nio que puede tenerse en cuenta, dado que la lexicografía no parece saber aún de la historia de la palabra.

3. «Fantasía» es vocablo cuyas dos acepciones de «representar por medio de imágenes las cosas ideales» y de "presunción», poseen desde Juan Ruiz hasta la época contemporánea una trayectoria más compleja de la que se ha expuesto hasta ahora; nuestro autor lo emplea en la primera de estas acepciones.

4. Para el Santo el uso de las imágenes está ordenado a mover la voluntad y despertar la devoción; han de ser así las imágenes realistas y emotivas, lo que supone un ideal artístico análogo al inmediatamente posterior del $\mathrm{Ba}$ rroco.

5. La propia palabra «imagen» en el sentido de «efigie de Dios, la Virgen o los santos» estaba documentada en Berceo, pero la hemos encontrado por lo menos - hacia un tercio de siglo antes- en la Vida de madona Santa María Egipciaqua.

6. San Juan converge con Erasmo al dibujar a Jesucristo en la Cruz: Erasmo había proclamado «remedio universal y maravilloso» el misterio de la Cruz.

7. El ideal de estilo de nuestro autor podemos cifrarlo en la inspiración, estudio y elección; de manera más abreviada otros autores lo han enunciado como ideal de inspiración y selección. El Santo además declara varias veces su conciencia de la inefabilidad de los estados místicos, aunque lucha por expresarlos mediante giros, comparaciones,...

8. San Juan de la Cruz puede simbolizar el auge que con todo el Renacimiento acabarían por tener el endecasílabo y la lira. A una tradición cuatrocentista de sonoridad rítmica y recurrencias insistentes se opone ahora en la serie artística la métrica silábica de metro largo; del siglo XV venía una tradición de ritmo sonoro pero no melodioso muy marcado, y la poética que introduce una originalidad y ruptura en la serie literaria es la de la métrica silábica y verso largo ${ }^{38}$.

9. El verso y la prosa sanjuanistas presentan a veces las figuras de la alegoría, la conjunción, la anáfora, la paronomasia,... La prosa asimismo se articula según bimembraciones, etc.

10. Programáticamente ha de hacerse una advertencia: el discurso en verso de nuestro autor parece haber sido más analizado hasta ahora; la estructura de su prosa requiere aún dedicación, como en general se ha de estudiar toda la

38 Cfr. para esta revolución poética F. ABAD, Literatura e historia de las mentalidades, Madrid, Cátedra, 1987, cap. VI. 
historia de la prosa castellana desde sus mismos origenes (tan poco analizados todavía) $^{39}$.

II. IDEAS Y DATOS PARA UNA HISTORIA DE LAS DOCTRINAS LITERARIAS EN ESPAÑA

\section{Hacia una historiografia de las ideas literarias}

El pasado humano posee una densidad tan grande que difícilmente pueden analizarlo los estudiosos con exhaustividad; ocurre también con la Historia de las ideas literarias y de las ideas lingüísticas en España. En tales Historias respectivas de nuestras ideas literarias y lingüísticas quedan cosas fundamentales por hacer: no es que haya huecos, necesidad de análisis monográficos, etc., sino que capítulos enteros están por hacer según decimos. El período que va de los primeros lustros del XIX hasta la guerra civil española parece sin duda el peor conocido, aunque para las doctrinas literarias se posea el panorama-que arranca no obstante de la Restauración- de Emilia de Zuleta, y también Alfredo Carballo ha escrito al respecto.

En realidad la historiografía nacionalista (Menéndez Pelayo, Menéndez Pidal, Américo Castro,...) se ha orientado más hacia un pasado glorioso visigodos, esplendor judaico, «ilustres hazañas»- que al análisis de la quiebra del Antiguo Régimen y de la España contemporánea y la «Edad de plata» de su cultura: ello ha llevado a la preterición en el estudio de nuestros siglos XVIII a XX. Por ejemplo la Historia de la lengua española suele llevarse de ordinario nada más que hasta 1713 , y es muy poco lo analizado desde entonces hasta nuestros días; asimismo la Historia de las ideas literarias no suele pasar del momento en que la dejó Menéndez Pelayo (inicios del Ochocientos); etc.

Queda pues un esfuerzo que sin duda es muy grande: simplemente la materialidad de localizar los textos para poder leerlos cuesta a veces bastante trabajo, y desde luego e ineludiblemente hay que leerlos y no simplemente hojearlos y citar de ellos un párrafo más o menos feliz que se encuentre; además hay que descubrir autores o testimonios que hasta ahora han pasado desa-

39 E] hilo argumental de nuestra presente contribución ha hecho que no nos refiramos a nombres importantes en la bibliografía en torno al Santo; no ha habido oportunidad, pero ello no quiere decir que no conozcamos o no estimemos en lo mucho que se merece a veces tal bibliografía. 
percibidos;... Para el caso concreto de búsqueda de los artículos periodísticos de Clarín ha dicho Roger L. Utt algo que bien puede aplicarse a nuestras materias: «Es inconcebible - manifiesta - que un solo investigador encuentre resistencia física, valor moral, dinero, apoyo editorial, lustros de vida suficientes, para ganar la batalla de rescate que tarde o temprano habrá que declarar sobre este terreno"; nosotros llevamos algún tiempo —si se permite esta referencia personal- leyendo de manera ordenada y completa en lo posible los textos adscribibles a la historia de las ideas literarias en España, y en efecto muchas veces nos hemos encontrado con la necesidad de esfuerzo físico para viajar e ir a las bibliotecas o de dinero para adquirir o fotocopiar textos, y con la necesidad siempre de un cierto arrojo moral.

Concebimos que la Historia de las ideas literarias en España es una materia secante con la de la propia Historia de la literatura, al igual que la Historia de las ideas lingüísticas resulta secante con la Historia de la lengua: las historias de la literatura y de la lengua fundamentan en parte su propia consistencia en las creencias literarias y lingüísticas de los sujetos del hablar. Importa pues para el análisis de la diacronía literaria y linguística el estudio de las ideas poéticas e idiomáticas.

Hace ya algunos años publicamos un trabajo con el título de $\alpha_{i}$ Es posible una Historia de las ideas lingütsticas en España?»; no queríamos decir con tal título que no se hubiese hecho hasta entonces nada al respecto, sino que esa Historia había que hacerla resueltamente y además apoyada en algunos criterios: lectura real y no meramente episódica de los textos, distinción de «paradigmas» y «tradiciones» científicos; hechos de historia del pensamiento y del pensamiento político que explican algunos textos o pasajes; etc. Hubiésemos sido necios si con nuestro título hubiéramos querido insinuar una falta total de investigación previa, pues ello no ocurre en absolutamente ninguna materia.

En definitiva nos encontramos ante la tarea - no poco costosa- de abordar el pasado de las ideas literarias y las ideas lingüísticas, tarea que requiere sobre todo un ascetismo de investigación, ascetismo o esfuerzo en la búsqueda de textos, en su lectura, y en su análisis adecuado.

\section{El estado de la cuestión}

La historia de las ideas poéticas en España podemos retrotraerla hasta el siglo XV: aparecen entonces los que podemos llamar con Pedro Sáinz Rodríguez «primitivos» de la materia. El primero de estos «primitivos» es Don Enrique de Villena, cuyo Arte de trovar data de 1423; Sánchez Cantón hizo la me- 
jor edición del texto ya en 1919, en el tomo VI de la «Revista de Filología Española». Luego nos encontramos con el «Prologus Baenensis» que es de hacia 1430 o de 1445, y con el «Prohemio e carta» del Marqués de Santillana de fines de los años cuarenta de esa centuria del Cuatrocientos.

Pasado el siglo XV llegamos a los siglos de oro literarios, que son los mejor analizados desde el presente punto de vista de la historia de las ideas literarias. Tras Menéndez Pelayo y dentro ya de los estudios actuales, Antonio Vilanova llevo a cabo una rigurosa exposición de los «Preceptistas españoles de los siglos XVI y XVII» (1953), y enseguida inició asimismo su trabajo Alberto Porqueras Mayo, posib.'zmente el estudioso que con mayor insistencia y nunca interrumpido aliento se ha dedicado a la materia. La labor de Porqueras ha cristalizado en sucesivos análisis monográficos sólo en parte recogidos en volumen, y en tres libros imprescindibles: Preceptiva dramática española (edición aumentada en 1972), La teoría poética en el Renacimiento y Manierismo españoles (1986), y La teoría poética en el Manierismo y Barroco españoles (1989); las dos últimas de estas obras nos parecen haber pasado relativamente desapercibidas. Desde luego tras Vilanova y Porqueras diferentes estudiosos han seguido haciendo aportaciones; de relieve por su tema es el libro de Antonio Martí sobre La Preceptiva retórica española en el Siglo de Oro (1972), y asimismo destacan por su sabiduría estética los análisis que hizo Emilio Orozco, etc., etc.

El estudio de las ideas estéticas en el siglo XVIII lo llevó a cabo - según bien se sabe- Menéndez Pelayo, y para la «España romántica» en sentido estricto (1808-1839) se cuenta con diferentes especialistas; uno de ellos es Ricardo Navas, quien asimismo con una dedicación nunca falta de aliento ha analizado las letras de la época y también sus doctrinas literarias.

Lo mismo que la historiografía general ha desatendido durante mucho tiempo la llamada «era isabelina» e incluso el sexenio democrático, la historiografía de las ideas literarias tiene asimismo un vacío para el segundo tercio del Ochocientos; según se sabe Emilia de Zuleta es autora de una pionera Historia de la crítica española contemporánea (edición notablemente aumentada en 1974), pero ella empieza hacia los años de la Restauración, y por otra parte tampoco puede dar acogida en un panorama de conjunto a distintas ideas de interés que aparecen al leer a los autores que menciona. No obstante su trabajo resulta pionero y orientativo para quienes escribimos después, y no entraría en justicia dejar de reconocerlo.

Por decirlo de una manera simplificada la Historia de nuestras ideas literarias se encuentra interrumpida donde la dejó Menéndez Pelayo, si bien a las dos centurias de oro - los siglos XVI y XVII - se han dedicado luego tanto panoramas como análisis monográficos; para el último tercio del Ochocientos y 
para las décadas iniciales de la centuria actual existe asimismo un primer panorama hecho por la profesora Zuleta.

Del mismo modo algún crítico contemporáneo dispone de un estudio con calado: así ocurre con Clarín, a quien se dedicó Sergio Beser.

\section{La generación de 1883}

Creemos en consecuencia que los años más necesitados de análisis en la diacronía de las ideas literarias en España son los de los dos tercios finales del siglo XIX y los de nuestra centuria; en los mismos van surgiendo sucesivos autores algunos de ellos decisivos.

Entre 1816 y 1830 aparece una generación de autores entre los que están Milà i Fontanals y Valera: de 1836 es el primer artículo de Milà —según indica Manuel Jorba-, y hacia 1836 podemos fijar el inicio del período que está más necesitado de estudio en la historia de las ideas literarias en España (cfr. M. Jorba, L'obra crítica $i$ erudita de Manuel Milà $i$ Fontanals, Barcelona, Abadia de Montserrat, 1989).

A esta generación nacida de 1816 a 1830 podemos denominarla «generación de 1854»; inmediatamente vendrán las que para entendernos podemos llamar «generación de 1868» y «generación de 1883»: nacen de 1831 a 1845 y de 1846 a 1860 . A la primera de estas dos últimas hornadas pertenecen Pedro Antonio de Alarcón, Bécquer, Giner de los Ríos o Galdós, autores todos ellos que no deben quedar ausentes de nuestra Historia de las ideas sobre poética; de la generación de 1883 son Manuel de la Revilla, la Pardo Bazán, Clarín, Palacio Valdés, Menéndez Pelayo,...: estamos ante un grupo decisivo de autores no bien estudiado aún.

En efecto a Clarín se le están dedicando esfuerzos que son además esfuerzos rigurosos, aunque algunos de sus textos hay que moverse bastante en bibliotecas para encontrarlos; Revilla - autor que nos parece de un gran relieve- apenas si acaba de encontrar a un primer estudioso: Carlos García Barrón ha publicado una monografía en torno a la Vida, obra y pensamiento de Manuel de la Revilla (Madrid, José Porrúa Turanzas, 1987); de doña Emilia ni es fácil localizar los textos ni se los tiene estudiados; etc.

A nosotros nos parece de un notorio relieve y atractivo la obra de Manuel de la Revilla, crítico sin embargo bastante olvidado por los filólogos: muy rara vez hemos visto que se le haga mención. Revilla editó -como se sabe- unos Principios generales de literatura e Historia de la literatura española con Pedro de Alcántara de cuya parte primera y teórica es autor único, y otros escritos 
suyos fueron reunidos en las Obras de D. Manuel de la Revilla publicadas por el Ateneo de Madrid en 1883; en general se trata de una figura significativa como testimonio de la marcha de la historia española toda en los tiempos del sexenio y del positivismo en España (a este respecto hay algunas indicaciones en José María Jover, Realidad y mito de la Primera República, Madrid, EspasaCalpe, 1991). Una Historia de las ideas literarias que haga justicia a los hechos y sepa calar en el pasado no puede dejar de reconocer la altura y los matices que presenta el nombre de Manuel de la Revilla.

A pesar de encontrarse fuera del mercado tampoco debe quedar inadvertido el tomo II de las Obras de Armando Palacio Valdés que publicó Aguilar hace años, ya que en él se contienen sus escritos críticos; por supuesto no cabe olvidar a doña Emilia Pardo Bazán.

Emilia es autora de La cuestión palpitante, ahora bien editada por José Manuel González Herrán (Barcelona, Anthropos, 1989), y como igualmente se sabe hizo tres volúmenes sucesivos acerca de La literatura francesa moderna, a saber: I, «El Romanticismo»; II, «La transición»; III, «El Naturalismo». Tales volúmenes poseen una distribución semejante, y así el primero se ocupa de los orígenes del Romanticismo, y de la lírica, el drama, la novela, la Historia y la crítica literaria del momento; el tomo segundo aborda «si hay un período que debe llamarse de transición», y luego la novela, el teatro, la lírica y la crítica en «su importancia creciente»; el volumen tercero aborda la doctrina naturalista, más la novela, el cuento, el teatro y la crítica de esos años.

Sin embargo el libro Lecciones de Literatura de nuestra autora se compone de cuentos, excepto en un capítulo primero que está dedicado a «La crítica moderna en Francia»; asimismo el tomo más antiguo De mi tierra presenta materiales de crítica literaria y de análisis linguístico. Efectivamente aparece en este volumen el escrito «iIdioma o dialecto?», en el que identifica al gallego como «un romance... traído... al estado de patué por el mutismo de la literatura y la fuerza de las circunstancias históricas, y renaciente en las letras desde la segunda mitad del siglo XIX»; el hablar «en dialecto» caracteriza a veces a los personajes tanto de Los pazos de Ulloa como de La madre Naturaleza.

Emilia Pardo Bazán fue autora también -entre otros libros de crítica- de uno muy atractivo y de gran interés para entender la marcha del pensamiento hacia el final del siglo pasado: se trata de La revolución y la novela en Rusia. Emilia delimita así lo que considera la «utopía» - y más tarde el «crimen»revolucionarios:

Durante la década de 1860 a 1870 apodérose de la mocedad rusa una especie de fiebre negadora, una feroz antipatía contra todo lo existente, 
autoridades, instituciones, ideas usuales y dogmas rancios... Hacia 1871, habiendo cruzado la frontera ecos de la Commune parisiense y emisarios de la Internacional europea, empezaron a moverse y agitarse los nihilistas. a asociarse clandestinamente y hacer propaganda: siete años después organizaron el terror, el asesinato y la voladura.

En cuanto a la novela nuestra autora analiza en ella un tono concomitante con esa actitud juvenil negadora, de "compasión y simpatía» por la infelicidad y la miseria y también «un tinte de piedad cristiana»; se descubre así «la chispa de bondad y nobleza encendida por Dios en el alma de los réprobos y criminales», y por ejemplo Tolstoy opina «que toda la doctrina de Jesucristo se cifra en un principio sólo: el de no resistir al malvado, o sea presentar la otra mejilla; no juzgar al prójimo, no airarse, no matar».

En las letras rusas - concluía Emilia - domina un principio anunciado ya por Gogol y que estaba preparado por el influjo de Schopenhauer: el del sentimiento y ternura hacia los seres inferiores.

Como vemos la obra crítica de la autora coruñesa presenta riqueza e interés, aunque parezca conocérsela tan poco; en la misma generación no hay ni que decir que la figura de Menéndez Pelayo es la de un gigante. Don Marcelino quedó estudiado en parte al cumplirse el centenario de su nacimiento y cuando por entonces fue objeto de una asignatura en el Preuniversitario; en tales ocasiones surgieron estudios que después no han sido puestos al día ni reeditados, lo que creemos hubiera resultado útil. En nuestros días no existe una obra en torno al Menéndez Pelayo estudioso de la literatura que quede a la dimensión de su talla; en un plano más general hemos podido encontrar (en librería de viejo) el texto sugerente de Guillermo de Torre Menéndez Pelayo y las dos Españas (Buenos Aires, Patronato Hispano-Argentino de Cultura, 1943).

\section{Generaciones del siglo XX}

Las primeras generaciones que se adscriben propiamente a nuestro siglo son las del 98, la del 14, la del 27 y la del 36; nacieron respectivamente entre 1861-1875, 1876-1890, 1891-1905 y 1906-1920. Reflexiones sobre la literatura se dan en autores de todas ellas, a veces con gran relieve histórico: Azorín, Dámaso Alonso, Menéndez Pidal,... 
Del Noventa y ocho hay que tener en cuenta - pero no sólo a ellos- a Unamuno, don Ramón Menéndez Pidal, Azorín, Andrenio, Antonio Machado, etc.; la generación del 14 incluye a D’Ors y a Ortega, y a Juan Ramón, a Pérez de Ayala, a Américo Castro, a don Tomás Navarro,a Federico de Onís, García Morente, Fernando Vela y Díez Canedo. García Morente no sólo escribió artículos que importan sino sobre todo analizó la estética de Kant, sobre la que en distintas ocasiones se oyen afirmaciones muy desviadas.

La crítica literaria de la generación del Veintisiete podría dar lugar sin duda a una monografía de conjunto: extraña incluso que no esté ya hecha; estamos nada menos que ante don Dámaso, Pedro Salinas, Guillermo de Torre, José Fernández Montesinos, etc. Dámaso Alonso va a quedar con toda probabilidad como el más alto crítico literario de la España del siglo XX, y siempre nos ha llamado la atención la cierta preterición en que se le tiene.

En efecto la publicación de la mayor parte de los tomos de las Obras Completas de nuestro autor ha ido pasando un poco en silencio, y aportaciones suyas de mucho relieve se diría que están desconocidas. La Estilística en España acostumbra a simplificarse en los solos nombres de Amado y Dámaso Alonso, y en una obra sola de cada uno de ellos: en el caso de don Dámaso, Poesía Española; no obstante el respeto a los hechos nos debe hacer reparar en el libro de 1944 de Manuel Criado de Val — aunque ese libro tenga vaguedadesAtlántico. Ensayo de una breve estilistica marina, y aún antes hay que advertir que los capítulos sobre historia de la lengua literaria española que empezó a publicar Menéndez Pidal en los años treinta, incluyen estrictos análisis de estilística literaria.

Por lo que se refiere a Dámaso Alonso su obra ha sido hecha en un inacabable esfuerzo de estudio y es muy amplia: no puede quedar reducida a uno o dos títulos. Sus perspectivas sobre la aportación de las letras españolas a la tradición de la novela moderna, por ejemplo, rara vez son recogidas o ampliadas, matizadas, etc.; a propósito de tales perspectivas diremos que a nosotros nos ha parecido encontrar un estímulo de las reflexiones de don Dámaso en el libro de Ramón Pérez de Ayala Principios y finales de la novela.

José Fernández Montesinos fue un grandísimo estudioso, ignorado sin embargo a veces o maltratado en otras ocasiones cuando se le alude; en fin no cabe olvidar tampoco la muy extensa e históricamente decisiva obra -por los testimonios que encierra - de Guillermo de Torre. Todavía con paciencia es posible encontrar en librería de viejo prácticamente el conjunto de los libros de Torre, pero falta sistematizarlos (de momento vid. Emilia de Zuleta, Guillermo de Torre, Buenos Aires, ECA, 1962).

No siempre han tenido fortuna los estudiosos de las letras en el Diccionario de literatura española e hispanoamericana que se publica en los mismos 
días en que escribimos estas páginas (Madrid, Alianza, 1993): de algunos de los nombres que hemos mencionado no se señala prácticamente $\longrightarrow$ se señala quizá menos de lo que sería adecuado- su trabajo teórico-literario o crítico-literario. Incluso un amigo querido encontramos que llega a decir de Menéndez Pidal que no puede señalarse que inventara nada: nosotros creemos por contra que conceptos teóricos tanto linguíísticos como literarios a él se deben; en su día quisimos probarlo con el Diccionario de lingüística de la escuela española (Madrid, Gredos, 1986), y volvemos a ello en un nuevo Diccionario de conceptos literarios que esperamos publicar pronto.

\section{Los ensayistas del 36}

La que podemos considerar «generación de 1936» ha sido conocida hasta ahora por sus poetas sobre todo, pero es sin duda una hornada de muy grandes estudiosos de las ciencias humanas: Juan Rof Carballo, José María Lacarra, Pedro Laín, José Luis Aranguren, Jaime Vicens, José Antonio Maravall, José Ferrater Mora, Julián Marías, Julio Caro Baroja, y otros tantos; de ellos Maravall se ocupó de cuestiones literarias, y son además estudiosos de las letras que pertenecen a esta generación Ricardo Gullón, Enrique Moreno Báez, Emilio Orozco, Guillermo Díaz Plaja, Vicente Gaos, José Luis Cano, José Manuel Blecua,...

Los textos literarios sirvieron a José Antonio Maravall como fuente para el análisis de las mentalidades sociales vigentes en la España del pasado: ilustró así el conservadurismo desconcertado ante las novedades de los tiempos de Fernando de Rojas, o el acecho del hombre contra el hombre que testimonian los discursos picarescos; del mismo modo interpretó el utopismo de Cervantes, y el surgir de la idea de "nación" que se cumple en los autores del Setecientos desde Feijoo, o la concepción del mundo social de Valle-Inclán (un Valle preburgués $\mathrm{y}$ anti-burgués).

De entre los estudiosos mencionados y que ya han desaparecido nos parece que destaca Emilio Orozco, autor asimismo visiblemente preterido a veces. Si se analizan bien sus estudios, puede percibirse en ellos una sabiduría estética y literaria que no es frecuente encontrarlas: el profesor granadino supo leer muy bien los textos de que se ocupaba y supo calar en la estética y la psicología literarias que encerraban. En particular su teorización y conceptuación del Manierismo y el Barroco, y de igual modo sus estudios sobre Góngora y en torno a la polémica de las Soledades, quedan inigualados hasta ahora. 
La siguiente generación de estudiosos es la de los que han nacido entre 1921 y 1935; se trata de autores vivos y en plena producción, por lo que al menos por nuestra parte detenemos el análisis al llegar a ellos. Uno sin embargo ha desaparecido ya — nos referimos a Mariano Baquero Goyanes-, y cabe así referirse a una obra ineluctablemente cerrada.

Baquero inició su trabajo dedicándose al cuento y a la novela españoles del siglo pasado, y en la fecha temprana de 1952 estudió por ejemplo lo mismo La Regenta que Su único hijo; enseguida se ocuparía asimismo de la obra novelística de la Pardo Bazán (1955). Con el tiempo este estudioso teorizaría sobre la novela y la novela contemporánea en general, e introdujo también el concepto crítico-literario de «perspectivismo».

\section{Un deseo final}

Al terminar los párrafos presentes queremos insistir en un hecho, que desde luego nos decimos en primer término a nosotros mismos: para hacer -en nuestro caso- la Historia de las ideas literarias en España hace falta sobre todo tener la paciencia de buscar y leer muchos textos. A veces los filólogos escriben sin haber leído, y esto al profesional que conozca su oficio no se le escapa; es muy fácil hacer referencias casi de memoria a muchos autores e insertar los títulos de sus libros, pero ello no contribuye al avance del saber. Por supuesto el contexto histórico del pasado en que han surgido las obras de ninguna manera puede quedar olvidado tampoco; las cosas tienen su verdadera razón de ser en las coordenadas en que aparecen.

[En pruebas estas páginas un siniestro en nuestra casa nos ha dejado sin vivienda y no sabemos si también sin los libros y materiales de muchos años de profesión. Queremos reafirmar el compromiso ético con la vocación de estudio, y con el respeto e interés que siempre debe prestarse a los estudiantes. 5-X-1993.] 